\title{
Penerapan Model Problem Based Learning dan Make A Match untuk Meningkatkan Hasil Belajar Matematika
}

\section{Laila Sya'bani ${ }^{1 *}$, Ni Wayan Arini ${ }^{2}$}

${ }^{12}$ Jurusan Pendidikan Guru Sekolah Dasar Fakultas Ilmu Pendidikan, Universitas Pendidikan Ganesha

\section{ART I CLE I N F O}

Article history:

Received January 21, 202

Revised February 03, 2021

Accepted April 08, 2021

Available online May 25, 2021

\section{Kata Kunci:}

Hasil Belajar Matematika,

Problem Based Learning, Make a Match

Keywords

Mathematics Result Learning Problem Based Learning,

Make a Match

\section{A B S T R A K}

Penelitian ini bertujuan untuk meningkatkan hasil belajar Matematika pada materi Keliling dan Luas Persegi dan Persegi Panjang melalui penerapan model Problem Based Learning dan Make a Match di kelas III SD Negeri 1 Granting.Jenis penelitian ini adalah penelitian tindakan kelas. Model penelitian yang digunakan yaitu model spiral tindakan kelas yang dikemukakan oleh Kemmis dan Mc. Taggart. Penelitian dilaksanakan dalam dua siklus. Setiap siklus terdiri dari empat tahapan yaitu;, perencanaan, pelaksanaan, observasi, dan refleksi. Subjek penelitian adalah siswa kelas III SD Negeri 1 Granting yang berjumlah 20 siswa. Pengumpulan data dilakukan melalui observasi dan tes. Data dianalisis dengan teknik deskriptif kualitatif dan deskriptif kuantitatif. Indikator keberhasilan penelitian ini ditandai dengan $80 \%$ siswa mencapai KKM atau $\geq 71$.Hasil penelitian menunjukkan bahwa model Problem Based Learning dan Make a Match dapat meningkatkan hasil belajar Matematika pada materi Keliling dan Luas Persegi dan Persegi Panjang. Hal itu dapat dibuktikan dengan peningkatan nilai rata-rata hasil belajar matematika pada materi Keliling dan Luas Persegi dan Persegi Panjang sebelum dilaksanakan tindakan adalah 64.5 dengan persentase ketuntasan sebesar $30 \%$, dan pada siklus I nilai rata-rata siswa meningkat menjadi 78 dengan persentase ketuntasan sebesar $65 \%$, sedangkan pada siklus II nilai rata-rata siswa juga meningkat menjadi 84.5 dengan persentase ketuntasan sebesar $85 \%$.

\begin{abstract}
A B S T R A C T
Currently, This research objectives were improved the results of mathematics learning through the application of the Problem Based Learning and Make a Match learning model in class III SD Negeri 1 Granting. The research type is collaborative classroom action research. The research model was used spiral classroom action research model proposed by Kemmis and Mc. Taggart. Research was held in two cycles. Every cycle composed from four stages including of planning, implementation, observation, and reflection. Research Subject is students of Class III SD Negeri 1 Granting including of 20 students. Data collection techniques were used observation and test. Data analyzed techniques were used qualitative and quantitative descriptive. Research success indicator is if $80 \%$ of students reach minimum completeness criteria or $\geq 71$. The research results were show that Problem Based Learning and Make a Match learning models can improve the results of mathematics learning. It could be proven with enhancement average value of mathematics learning results before held action is 64.5 with completeness percentage of $30 \%$, and on cycle I the students' average value increase to 78 with completeness percentage of $65 \%$, while on cycle II the students' average value increase to 84.5 with completeness percentage of $85 \%$.
\end{abstract}

\section{Pendahuluan}

Keberhasilan pendidikan dapat ditunjukkan dari kualitas pendidikan yang ada, dimana kualitas pendidikan itu meliputi kualitas proses maupun kualitas lulusan. jadi pendidikan dikatakan berhasil apabila proses belajar- mengajarnya berjalan dengan baik serta menghasilkan output yang berkualitas. di dalam peningkatan mutu pendidikan perlu efisiensi pendidikan, yang mempunyai arti bahwa proses pendidikan harus mencapai hasil yang maksimal dengan biaya yang wajar. dalam pandangan yang lebih luas efisiensi pendidikan berkaitan dengan profesionalisme dan manajemen pendidikan yang di dalamnya mengandung disiplin, kesetiaan dan etos kerja. hal ini kurang disadari oleh para penyelenggara pendidikan yang berada di daerah pada umumnya, yang pada gilirannya mengakibatkan munculnya permasalahan pada dunia pendidikan (Maesaroh, 1970).

Dalam Kamus Besar Bahasa Indonesia (KBBI) pendidikan berasal dari kata dasar didik (mendidik), yaitu : memelihara dan memberi latihan (ajaran, pimpinan) mengenai akhlak dan kecerdasan pikiran. Sedangkan pendidikan mempunyai pengertian : proses pengubahan sikap dan tata laku seseorang atau kelompok orang dalam usaha mendewasakan manusia melalui upaya pengajaran dan latihan, proses perbuatan, cara mendidik. Ki Hajar Dewantara mengartikan pendidikan sebagai daya upaya untuk 
memajukan budi pekerti, pikiran serta jasmani anak, agar dapat memajukan kesempurnaan hidup yaitu hidup dan menghidupkan anak yang selaras dengan alam dan masyarakatnya. Dari pengertian-pengertian dan analisis yang ada maka bisa disimpulkan bahwa pendidikan adalah upaya menuntun anak sejak lahir untuk mencapai kedewasaan jasmani dan rohani, dalam interaksi alam beserta lingkungannya.(Nurkholis, 2013).

Matematika adalah suatu bidang ilmu yang menglobal. Ia hidup di alam tanpa batas. Tak ada negara yang menolak kehadirannya dan tak ada agama yang melarang untuk mempelajarinya. Ia tidak mau berpolitik dan tidak mau pula dipolitisasikan. Eksistensinya di dunia sangat dibutuhkan dan kehidupannya terus berkembang sejalan dengan tuntutan kebutuhan umat manusia, karena tidak ada kegiatan/tingkah laku manusia yang terlepas dari matematika. Matematika telah menjadi ratu sekaligus pelayan bagi ilmu yang lain (Kamarullah, 2017).

Matematika mempelajari tentang keteraturan, tentang struktur yang terorganisasikan, konsepkonsep matematika tersusun secara hirarkis, berstruktur dan sistematika, mulai dari konsep yang paling sederhana sampai pada konsep paling kompleks. Dalam matematika objek dasar yang dipelajari adalah abtraks, sehingg disebut objek mental, objek itu merupakan objek pikiran. Objek dasar itu meliputi: Simbol, merupakan suatu lambang dari suatu objek atau pernyataan (Hasratuddin, 2013). Pendidikan merupakan kegiatan yang kompleks, dan meliputi berbagai komponen yang berkaitan erat satu sama lain. Oleh sebab itu, apabila pendidikan ingin dilaksanakan secara terencana dan teratur, maka berbagai faktor yang terlibat dalam pendidikan harus dipahami terlebih dahulu. Berbagai komponen dalam sistem pendidikan, baik secara mikro maupun dalam kajian makro perlu dikenali secara mendalam sehingga komponen-komponen tersebut dapat difungsikan dan dikembangkan guna mengoptimalkan garapan pendidikan tersebut ke arah pencapaian tujuan pendidikan yang ditetapkan (Arsyad, 2016).

Matematika sebagai salah satu bidang studi yang diajarkan di lembaga pendidikan formal merupakan salah satu bagian penting dalam upaya meningkatkan mutu pendidikan. Pelajaran matematika adalah suatu pelajaran yang berhubungan dengan banyak konsep. Konsep merupakan ide abstrak yang dengannya kita dapat mengelompokkan obyek-obyek kedalam contoh atau bukan contoh. Konsep-konsep dalam matematika memiliki keterkaitan satu dengan yang lainnya. Saling keterkaitannya antar konsep materi satu dan yang lainnya merupakan bukti akan pentingnya pemahaman konsep matematika. Karenanya, siswa belum bisa memahami suatu materi jika belum memahami materi sebelumnya atau materi prasyarat dari materi yang akan pelajari (Novitasari, 2016).

Bukti bahwa seseorang telah belajar ialah terjadinya perubahan tingkah laku pada orang tersebut, misalnya dari tidak tahu menjadi tahu, dan dari tidak mengerti menjadi mengerti (Hamalik, 2008: 30). Menurut Dimyati dan Mudjiono (1999), hasil belajar merupakan hal yang dapat dipandang dari dua sisi yaitu sisi siswa dan dari sisi guru. Dari sisi siswa, hasil belajar merupakan tingkat perkembangan mental yang lebih baik bila dibandingkan pada saat sebelum belajar (Sulastri and Dkk, 2014).

Observasi terhadap kegiatan pembelajaran di kelas III SD Negeri 1 Granting dan berdasarkan hasil wawancara dengan guru dan siswa serta hasil observasi, menunjukkan bahwa siswa cenderung pasif ketika pembelajaran berlangsung, terutama pada saat ada mata pelajaran Matematika. Siswa masih sekedar mendengarkan penjelasan dari guru dan belum banyak melakukan kegiatan tanya jawab ataupun tukar pendapat dan lebih memilih bercerita atau main dengan temannya. Hal ini menunjukkan bahwa partisipasi siswa kelas III dalam pembelajaran Matematika masih rendah.

Selama pembelajaran guru menjadi pelaku utama dalam kelas sehingga siswa lebih banyak diam dan tidak berpartisipasi dalam pembelajaran. Pembelajaran yang dilakukan belum memberdayakan siswa, sehingga siswa belum diberi kesempatan untuk berpartisipasi dalam menemukan sendiri pengetahuannya. Kondisi belajar yang demikian tentu jauh dari implementasi pembelajaran dengan partisipasi aktif siswa sehingga potensi siswa belum dikembangkan secara optimal.

Kurangnya partisipasi siswa dalam pembelajaran juga terlihat ketika pembelajaran berlangsung siswa hanya mendengarkan ceramah dari guru tanpa diikuti kegiatan tanya jawab, tukar pendapat, diskusi, ataupun keikutsertaan dalam kelompok. Siswa masih menganggap guru adalah satu-satunya sumber berlajar. Keadaan seperti ini jelas menunjukkan bahwa siswa tidak berpartisipasi dalam kegiatan belajar untuk menemukan sendiri pengetahuannya karena hanya sekedar menerima sajian materi dari guru. Selain itu, hasil dari wawancara dengan guru kelas III SD Negeri 1 Granting didapatkan bahwa nilai siswa masih rendah terutama pada mata pelajaran Matematika materi tentang keliling bangun datar.

Berdasarkan fakta-fakta yang ditemukan di lapangan dapat diambil kesimpulan bahwa pembelajaran Matematika di kelas III SD Negeri 1 Granting sudah berusaha mengaktifkan siswa untuk berpartisipasi dalam pembelajaran akan tetapi masih kurang maksimal, sehingga tingkat partisipasi siswa dalam pembelajaran masih tergolong rendah. Partisipasi siswa yang masih rendah ditunjukan dengan sedikitnya siswa yang bertanya, berpendapat dan ikut serta dalam kegiatan diskusi kelompok. 
Partisipasi siswa sangat penting dalam pembelajaran karena dengan siswa berpartisipasi maka potensi siswa akan dikembangkan secara maksimal. Partisipasi siswa dalam pembelajaran dapat diwujudkan menjadi beberapa kegiatan seperti tanya jawab, tukar pendapat, pemberian tugas atau diskusi kelompok. Dengan demikian guru diharapkan mampu memberi kesempatan pada siswa untuk dapat berpartisipasi aktif seperti dalam beberapa kegiatan di atas agar pembelajaran menjadi lebih bermakna. Salah satu upaya untuk menjadikan siswa berpartisipasi adalah menerapkan model pembelajaran yang dapat memberikan siswa pengalaman belajar dengan berbagai kegiatan belajar sehingga siswa tidak hanya menerima materi dari guru akan tetapi menemukan sendiri pengetahuannya melalui kegiatan belajar.

Berdasarkan uraian di atas peneliti ingin memberikan suatu alternatif untuk mengatasi permasalahan tersebut dengan menggunakan model Problem Based Learning dan Make a Match dalam kegiatan belajar mengajar di kelas. Model pembelajaran Problem Based Learning merupakan model pengajaran yang bercirikan adanya permasalahan nyata sebagai konteks untuk para siswa belajar berfikir kritis dan keterampilan memecahkan masalah dan memperoleh pengetahuan. Sedangkan model pembelajaran Make a Match merupakan sistem pembelajaran yang mengutamakan penanaman kemampuan sosial terutama kemampuan bekerja sama, kemampuan berinteraksi disamping kemampuan berpikir cepat melalui permainan mencari pasangan dengan dibantu kartu. Kedua model tersebut dipilih karena memiliki kelebihan, salah satunya dapat meningkatkan partisipasi siswa dalam pembelajaran.

PBL merupakan suatu pendekatan pembelajaran yang menggunakan masalah dunia nyata sebagai suatu konteks bagi peserta didik untuk belajar tentang cara berpikir kritis dan keterampilan pemecahan masalah, serta untuk memperoleh pengetahuan dan konsep yang esensial dari materi pelajaran. PBL merupakan pembelajaran berdasarkan teori kognitif yang didalamnya termasuk teori belajar konstruktivisme. Menurut teori konstruktivisme, keterampilan berpikir dan memecahkan masalah dapat dikembangkan jika peserta didik melakukan sendiri, menemukan, dan memindahkan kekomplekan pengetahuan yang ada (Lestari, Ansori and Karyadi, 2017).

Yuan (2008) menyatakan bahwa PBL adalah model pembelajaran yang berpusat pada peserta didik untuk belajar, memungkinkan berpartisipasi, dan menghadapi situasi pemecahan dalam kerja kelompok kecil selama proses pembelajaran.Menurut Muhson (2009), PBL merupakan metode belajar yang menggunakan masalah sebagai langkah awal dalam mengumpulkan dan mengintegrasikan pengetahuan baru. Menurut Keziah (2010), PBL merupakan pembelajaran yang memfasilitasi peserta didik belajar melalui pemecahan masalah dunia nyata dan autentik serta mengintegrasikan pengetahuan lintas disiplin (Syamsiara Nur, 2017).

Menurut (Siswono, 2005), Problem Based Learning adalah suatu pendekatan pembelajaran yang dimulai dengan mengajukan masalah dan dilanjutkan dengan menyelesaikan masalah tersebut. Untuk menyelesaikan masalah itu menurut (Ha Roh, 2008), peserta didik memerlukan pengetahuan baru untuk menemukan solusinya (Nugroho, Chotim, \& Dwijanto, 2013, p. 50). Masalah tersebut dapat meningkatkan kemampuan berpikir tingkat tinggi siswa yang di dalamnya mencakup kemampuan berfikir analitis. Menurut filsuf dan pendidik (John Dewey, 1938) bahwa "masalah adalah stimulus untuk berpikir"(Assegaff and Sontani, 2016).

Berdasarkan uraian yang telah dijelaskan di atas, penulis tertarik untuk melakukan penelitian dengan judul "Penerapan Model Problem Based Learning dan Make a Match Untuk Meningkatkan Hasil Belajar pada Materi Keliling dan Luas Persegi dan Persegi Panjang di Kelas III Sekolah Dasar Negeri 1 Granting Semester Dua Tahun Pelajaran 2018/2019."

Berdasarkan pembatasan masalah, maka dalam penelitian ini dapat diajukan rumusan masalah “Apakah penerapan model Problem Based Learning dan Make a Match dapat meningkatkan hasil belajar siswa pada materi Keliling dan Luas Persegi dan Persegi Panjang di Kelas III SD Negeri 1 Granting?

Adapun tujuan penelitian dalam penelitian ini adalah "Untuk meningkatkan hasil belajar siswa pada materi Keliling dan Luas Persegi dan Persegi Panjang kelas III SD Negeri 1 Granting melalui penerapan model Problem Based Learning dan Make a Match."

\section{Metode}

Rancangan penelitian yang digunakan dalam penelitian ini adalah penelitian tindakan kelas. Penelitian tindakan kelas ini menggunakan desain penelitian model Kemmis dan Mc Taggart. Pada model Kemmis dan Mc Taggart terdiri dari beberapa perangkat yang satu perangkatnya terdiri atas empat komponen yaitu perencanaan (planning), tindakan (action), pengamatan (observing), dan refleksi (reflecting). Keempat komponen ini dikatakan sebagai satu siklus. Berikut ini merupakan gambaran bentuk desainnya: 


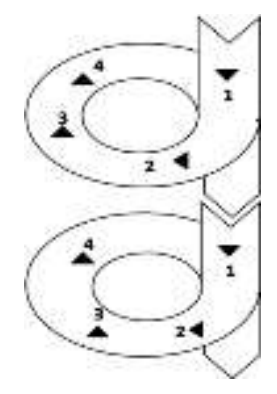

Gambar 2. Siklus PTK Model Kemmis \& Mc Taggart

Keterangan

1 : Perencanaan I

2 dan 3 : Pelaksanaan Tindakan dan Pengamatan I

$4 \quad$ : Refleksi I

$5 \quad$ : Perencanaan II

6 dan 7 : Pelaksanaan Tindakan dan Pengamatan II

$8 \quad$ : Refleksi II

Desain penelitian yang akan dilakukan peneliti memiliki dua siklus. Setiap siklus pelaksanaan tindakannya meliputiempat komponen tindakan yaitu perencanaan, tindakan, pengamatan, dan refleksi dalam suatu spiral yang saling terkait:

a. Perencanaan

1) Menetapkan waktu pelaksanaan penelitian tindakan kelas. Penelitian diadakan satu kali dalam seminggu sesuai jadwal di kelas III SD Negeri 1 Granting

2) Membuat Rencana Pelaksanaan Pembelajaran (RPP) tentang materi yang akan diajarkan. RPP disusun oleh peneliti dengan pertimbangan dari dosen pembimbing dan guru kelas sebagai pedoman dalam pelaksanaan kegiatan pembelajaran yang akan dilakukan dengan model pembelajaran Problem Based Learning dan Make a Macth.

3) Mempersiapkan materi dan membuat media pembelajaran.

4) Menyiapkan lembar observasi untuk mengamati partisipasi siswa dalam pembelajaran dengan model pembelajaran Problem Based Learning dan Make a Macth.

5) Menyiapkan daftar pertanyaan sebagai pedoman wawancara untuk guru kelas. b. Tindakan

Pada tahap ini peneliti melaksanakan tindakan yang sudah dirancang sesuai dengan Rencana Pelaksanaan Pembelajaran (RPP) dengan model pembelajaran Problem Based Learning dan Make a Match. Peneliti juga dibantu oleh satu orang pengamat untuk mengamati partisipasi siswa dan kegiatan guru dalam proses pembelajaran.

1) Kegiatan awal

a) Guru membuka pembelajaran dan mempersiapkan siswa untuk mengikuti kegiatan pembelajaran.

b) Guru memberikan apersepsi dan menjelaskan manfaat dari mempelajari materi.

c) Memperkenalkan model make a match kepada siswa

2) Kegiatan inti

a) Orientasi siswa pada masalah

(1) Guru menyampaikan tujuan pembelajaran bahwa siswa belajar tentang masalah sehari-hari yang berkaitan dengan matematika.

(2) Guru dan siswa melakukan tanya jawab tentang masalah pribadi yang dialami siswa.

(3) Guru memberikan motivasi agar siswa aktif dalam pembelajaran dengan cara memberitahukan kepada siswa bahwa semua aktivitas siswa akan dinilai sebagai nilai afektif dan psikomotor.

(4) Siswa melakukan tanya jawab tentang masalah pribadi yang pernah dialami dan masalah sosial yang ada di lingkungan sekitar.

b) Mengorganisasi siswa untuk belajar

(1) Siswa membentuk kelompok dengan masing-masing kelompok terdiri dari 4 siswa.

(2) Siswa berkumpul dengan teman sekelompoknya untuk melakukan diskusi.

(3) Siswa membagi tugas dengan teman satu kelompok dengan bimbingan guru.

(4) Guru membagikan Lembar Kerja Peserta Didik (LKPD) tentang masalah sehari-hari yang berkaitan dengan matematika kepada masing-masing kelompok.

(5) Siswa memahami langkah-langkah yang harus dilakukan dalam LKPD dengan bantuan bimbingan guru. 
(6) Siswa menggunakan kartu yang dibagikan guru untuk mencari pasangannya/jawabannya pada kelompok lain

c) Investigasi secara individu atau kelompok

(1) Siswa melakukan kegiatan investigasi bersama teman sekelompok sesuai dengan langkahlangkah pada LKPD.

(2) Siswa melakukan wawancara antar teman dalam satu kelompok terkait masalah pribadi yang pernah dialami.

(3) Guru membimbing setiap kelompok dalam melakukan investigasi.

d) Mengembangkan dan menyajikan hasil karya

(1) Siswa membuat laporan hasil penyidikan.

(2) Guru membimbing kegiatan penyusunan laporan penyidikan, membantu siswa jika ada yang mengalami kesulitan.

e) Menganalisis dan mengevaluasi proses pemecahan masalah.

(1) Setiap kelompok mempresentasikan hasil diskusi.

(2) Kelompok lain memperhatikan dan memberikan tanggapan terkait hasil presentasi.

(3) Siswa melakukan tanya jawab dengan siswa terkait materi yang sudah dipelajari, meluruskan kesalahpahaman dan membuat kesimpulan

(4) Siswa mengerjakan soal test hasil belajar sebanyak sepuluh soal sebagai penilaian hasil belajar aspek kognitif.

3) Kegiatan akhir

a)Siswa mengulangi kembali hasil kesimpulan dari pembelajaran.

b)Siswa diberikan reward sesuai dengan hasil yang dikerjakan.

c)Siswa diberikan soal evaluasi.

d)Guru menutup pembelajaran dengan salam dan doa.

c. Pengamatan

Pengamatan atau observasi merupakan upaya mengamati pelaksanaan tindakan. Observasi dilakukan pada saat pembelajaran berlangsung dan mengacu pada instrumen yang telah dibuat. Hasil pengamatan nantinya digunakan sebagai landasan untuk melakukan refleksi. Aspek-aspek yang diamati sesuai dengan indikator partisipasi yang sudah ditentukan sebelumnya, antara lain sebagai berikut:

1) Kegiatan Mendengarkan

a) Siswa mendengarkan penjelasan dari guru.

2) Kegiatan Menulis

a) Siswa mencatat materi yang sudah diberikan oleh guru.

b) Siswa mengerjakan tugas individu yang diberikan guru.

3) Kegiatan Lisan

a) Siswa berani mengajukan pertanyaan.

b) Siswa berani mengungkapkan pendapat.

c) Siswa ikut serta dalam diskusi kelompok.

d) Siswa mampu menjawab pertanyaan yang diberikan guru.

4) Kegiatan Visual

a) Siswa melakukan pengamatan dengan serius.

b) Siswa mau membaca materi yang diberikan guru.

d.Refleksi

Pada tahap refleksi (reflecting) peneliti melakukan analisis, mendiskusikan data yang sudah diperoleh, dan menyususn rencana tindakan yang diperoleh melalui kegiatan observasi. Perubahan rencana pada siklus berikutnya dapat dilakukan jika hasil pada tindakan pertama masih belum sesuai dengan tujuan yang diharapkan dengan mengacu pada hasil refleksi sebelumnya. Siklus dihentikan jika peneliti dan guru sepakat bahwa pembelajaran Matematika yang dilakukan sudah sesuai dengan rencana dan telah mampu meningkatkan hasil belajar dan partisipasi siswa sesuai dengan kriteria yang sudah ditentukan sebelumnya.

\section{Hasil Dan Pembahasan}

Nilai Penelitian ini diawali dengan melakukan observasi awal untuk mengidentifikasi masalah dan wawancara dengan guru serta siswa kelas III SD Negeri 1 Granting terkait dengan mata pelajaran Matematika.

Berdasarkan hasil wawancara dan observasi diketahui bahwa materi keliling bangun datar yang hanya dijelaskan melalui ceramah dan sedikit contoh membuat siswa kesulitan keliling bangun datar dan siswa hanya mampu meniru dari contoh tanpa mengenali cara keliling bangun datar tersebut. Tampak siswa kurang terampil dalam keliling bangun datar. Peneliti kemudian melakukan pre-test keliling bangun 
datar kepada setiap siswa kelas III yang bertujuan untuk mengetahui data nilai awal hasil belajar dalam keliling bangun datar sebelum diterapkannya model pembelajaran Problem Based Learning dan Make a Match yang nantinya digunakan untuk membandingkan dengan data penelitian yang diperoleh sesudah penerapan model pembelajaran Problem Based Learning dan Make a Match. Berikut ini adalah data nilai pre-test keliling bangun datar di kelas III SD Negeri 1 Granting.

Tabel 2. Nilai Pre-test Pra Tindakan Keliling bangun datar Kelas III

\begin{tabular}{|c|c|c|c|c|}
\hline No & Nama Siswa (Inisial) & Nilai & $\begin{array}{l}\text { Keterangan } \\
\text { Tuntas } \\
\end{array}$ & Tidak Tuntas \\
\hline 1 & ADNS & 60 & - & $\checkmark$ \\
\hline 2 & ATP & 50 & - & $\checkmark$ \\
\hline 3 & DA & 80 & $\checkmark$ & - \\
\hline 4 & DPR & 70 & - & $\checkmark$ \\
\hline 5 & FAN & 50 & - & $\checkmark$ \\
\hline 6 & FR & 60 & - & $\checkmark$ \\
\hline 7 & $\mathrm{FF}$ & 80 & $\checkmark$ & - \\
\hline 8 & $\mathrm{HN}$ & 90 & $\checkmark$ & - \\
\hline 9 & MKA & 40 & - & $\checkmark$ \\
\hline 10 & MTK & 60 & - & $\checkmark$ \\
\hline 11 & NPV & 90 & $\checkmark$ & - \\
\hline 12 & NR & 60 & - & $\checkmark$ \\
\hline 13 & RER & 60 & - & $\checkmark$ \\
\hline 14 & RCD & 70 & - & $\checkmark$ \\
\hline 15 & RA & 60 & - & $\checkmark$ \\
\hline 16 & RPM & 30 & - & $\checkmark$ \\
\hline 17 & SA & 80 & $\checkmark$ & - \\
\hline 18 & TR & 60 & - & $\checkmark$ \\
\hline 19 & $\mathrm{FF}$ & 80 & $\checkmark$ & - \\
\hline 20 & $\mathrm{FIH}$ & 60 & - & $\checkmark$ \\
\hline \multicolumn{2}{|c|}{ Jumlah } & 1290 & 6 & 14 \\
\hline \multicolumn{2}{|c|}{ Rata-Rata } & 64,5 & & \\
\hline \multicolumn{2}{|c|}{ Nilai Tertinggi } & 90 & - & - \\
\hline \multicolumn{2}{|c|}{ Nilai Terendah } & 30 & & \\
\hline \multicolumn{2}{|c|}{ Ketuntasan (\%) } & - & $30 \%$ & $70 \%$ \\
\hline
\end{tabular}

Dari Tabel diatas, hasil belajar siswa sebelum diterapkan model pembelajaran Problem Based Learning dan Make a Match pada siswa kelas III SD Negeri 1 Granting yang telah diterangkan di atas dapat disajikan dalam bentuk Gambar 3 sebagai berikut.

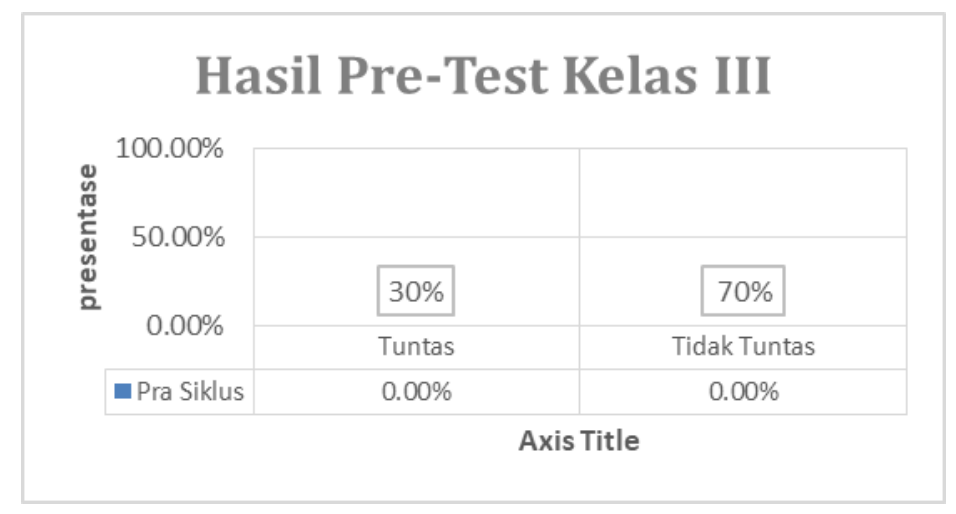

Gambar 3. Hasil Tingkat Ketuntasan Pre-test 
Berdasarkan Tabel 12 dan Gambar 3 di atas, diketahui bahwa baru 6 siswa yang telah memenuhi Kriteria Ketuntasan Minimal (KKM), sedangkan 14 siswa lainnya belum memenuhi KKM. Persentase untuk tingkat ketuntasan sebesar 30\% dan yang tidak tuntas 70\%. Nilai rata-rata kelas dihitung dari jumlah keseluruhan nilai siswa adalah 64,5. Sebanyak 6 (30\%) mendapat nilai di atas nilai kriteria ketuntasan minimal, sedangkan 14 (70\%) siswa mendapatkan nilai kurang dari 71. Hasil rata-rata seluruh kelas menunjukan bahwa nilai untuk keliling bangun datar masih di bawah Kriteria Ketuntasan Minimal (KKM) yaitu 71. Nilai 71 merupakan nilai kriteria ketuntasan minimal pada mata pelajaran matematika yang ditetapkan sekolah, dengan melihat hasil yang diperoleh siswa, peneliti melakukan penelitian tindakan kelas sebagai upaya meningkatkan hasil belajar siswa kelas III SD Negeri 1 Granting dengan menggunakan model pembelajaran Problem Based Learning dan Make a Match sehingga ketuntasan kelas dapat tercapai, yaitu setidak-tidaknya $80 \%$ dari jumlah keseluruhan siswa dengan nilai $\geq 71$. Jika belum mendapatkan $80 \%$ maka pembelajaran tersebut dikatakan belum mencapai kriteria ketuntasan.

Observasi hasil belajar dilakukan untuk menelaah hasil belajar siswa setelah diberikan tindakan. Proses pembelajaran pada siklus I sudah berjalan cukup baik. Post-test pembelajaran dilaksanakan pada hari Kamis, 31 Januari 2019 dengan menggunakan soal mengkonversikan waktu tahun, bulan, minggu dan hari yang berjumlah 10 butir soal. Hasil dari post-test siklus I dapat dilihat sebagai berikut.

Tabel 3. Rekapitulasi Nilai Post-test Siswa Siklus I

\begin{tabular}{|c|c|c|c|c|}
\hline \multirow{2}{*}{ No } & \multirow{2}{*}{ Nama Siswa (Inisial) } & \multirow{2}{*}{ Nilai } & \multicolumn{2}{|c|}{ Keterangan } \\
\hline & & & Tuntas & Tidak Tuntas \\
\hline 1 & ADNS & 80 & $\checkmark$ & - \\
\hline 2 & ATP & 40 & - & $\checkmark$ \\
\hline 3 & DA & 90 & $\checkmark$ & - \\
\hline 4 & DPR & 70 & - & $\checkmark$ \\
\hline 5 & FAN & 60 & - & $\checkmark$ \\
\hline 6 & FR & 100 & $\checkmark$ & - \\
\hline 7 & $\mathrm{FF}$ & 80 & $\checkmark$ & - \\
\hline 8 & $\mathrm{HN}$ & 100 & $\checkmark$ & - \\
\hline 9 & MKA & 60 & - & $\checkmark$ \\
\hline 10 & MTK & 90 & $\checkmark$ & - \\
\hline 11 & NPV & 80 & $\checkmark$ & - \\
\hline 12 & NR & 100 & $\checkmark$ & - \\
\hline 13 & RER & 90 & $\checkmark$ & - \\
\hline 14 & RCD & 80 & $\checkmark$ & - \\
\hline 15 & $\mathrm{RA}$ & 100 & $\checkmark$ & - \\
\hline 16 & RPM & 60 & - & $\checkmark$ \\
\hline 17 & SA & 80 & $\checkmark$ & - \\
\hline 18 & TR & 60 & - & $\checkmark$ \\
\hline 19 & $\mathrm{FF}$ & 80 & $\checkmark$ & - \\
\hline \multirow[t]{2}{*}{20} & FIH & 60 & - & $\checkmark$ \\
\hline & JUMLAH & 1560 & 13 & 7 \\
\hline \multicolumn{2}{|c|}{ Rata-rata } & 78 & & \\
\hline \multicolumn{2}{|c|}{ Nilai Tertinggi } & 100 & - & - \\
\hline \multicolumn{2}{|c|}{ Nilai Terendah } & 40 & & \\
\hline \multicolumn{2}{|c|}{ Ketuntasan (\%) } & - & $65 \%$ & $35 \%$ \\
\hline
\end{tabular}

Berdasarkan data di atas, ada 13 siswa yang telah memenuhi kriteria ketuntasan minimal (KKM) yaitu dengan perolehan nilai $\geq 71$. Persentase ketuntasan pada siklus I ini adalah $65 \%$, sedangkan siswa yang belum memenuhi KKM ada 6 siswa atau 35\%. Nilai terendah siswa pada post-test siklus I adalah 40, sedangkan nilai tertinggi adalah 100. Data di atas dapat digambarkan dalam diagram batang sebagai berikut. 


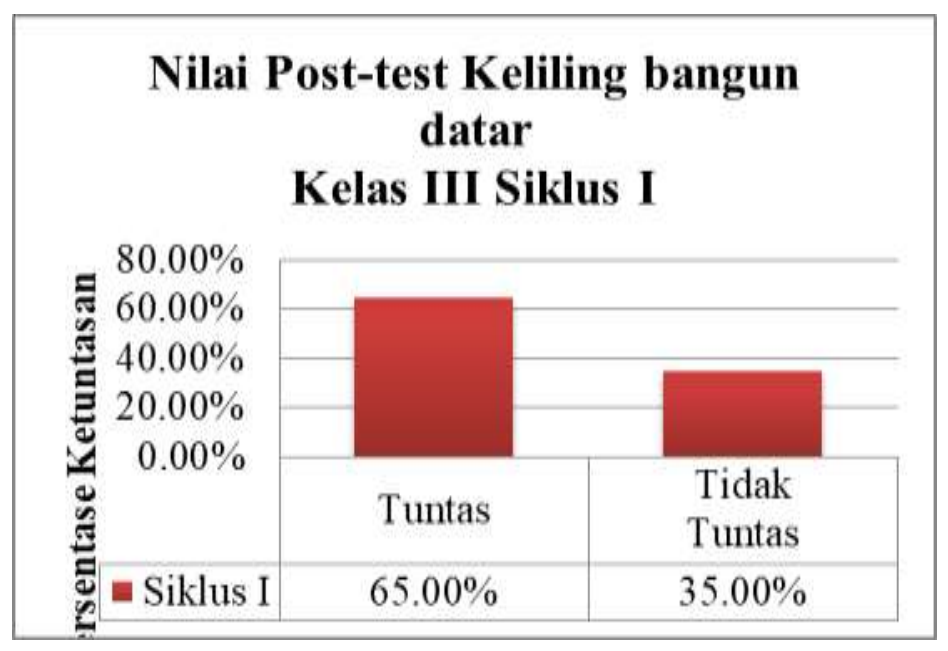

Gambar 4. Hasil belajar didapat dari post-test

Hasil belajar didapat dari post-test yang dilakukan pada akhir siklus II. Nilai post-test ditelaah untuk mengetahui hasil belajar siswa setelah diberi tindakan yang didasarkan dari hasil refleksi siklus I. Berikut ini adalah data nilai post-test pada siklus II.

Tabel 4. Hasil Belajar Siswa Siklus II

\begin{tabular}{|c|c|c|c|c|}
\hline \multirow[b]{2}{*}{ No } & \multirow[b]{2}{*}{ Nama Siswa (Inisial) } & \multirow[b]{2}{*}{ Nilai } & \multicolumn{2}{|c|}{ Keterangan } \\
\hline & & & Tuntas & Tidak Tuntas \\
\hline 1 & ADNS & 80 & $\checkmark$ & - \\
\hline 2 & ATP & 60 & - & $\checkmark$ \\
\hline 3 & $\mathrm{DA}$ & 80 & $\checkmark$ & - \\
\hline 4 & DPR & 90 & $\checkmark$ & - \\
\hline 5 & FAN & 80 & $\checkmark$ & - \\
\hline 6 & FR & 90 & $\checkmark$ & - \\
\hline 7 & $\mathrm{FF}$ & 80 & $\checkmark$ & - \\
\hline 8 & $\mathrm{HN}$ & 100 & $\checkmark$ & - \\
\hline 9 & MKA & 70 & - & $\checkmark$ \\
\hline 10 & MTK & 90 & $\checkmark$ & - \\
\hline 11 & NPV & 90 & $\checkmark$ & - \\
\hline 12 & NR & 100 & $\checkmark$ & - \\
\hline 13 & RER & 100 & $\checkmark$ & - \\
\hline 14 & RCD & 100 & $\checkmark$ & - \\
\hline 15 & RA & 90 & $\checkmark$ & - \\
\hline 16 & RPM & 60 & - & $\checkmark$ \\
\hline 17 & SA & 80 & $\checkmark$ & - \\
\hline 18 & TR & 90 & $\checkmark$ & - \\
\hline 19 & $\mathrm{FF}$ & 90 & $\checkmark$ & - \\
\hline 20 & $\mathrm{FIH}$ & 70 & - & $\checkmark$ \\
\hline Jumlah & & 1690 & 17 & 3 \\
\hline Rata-r & & 84,5 & & \\
\hline Nilai T & & 100 & - & - \\
\hline Nilai T & lah & 60 & & \\
\hline Ketunt & $(\%)$ & - & $85 \%$ & $15 \%$ \\
\hline
\end{tabular}

Berdasarkan Tabel di atas, ada 20 siswa yang telah memenuhi Kriteria Ketuntasan Minimal (KKM) yaitu dengan perolehan nilai $\geq 71$. Persentase ketuntasan pada siklus II adalah $85 \%$ atau 17 siswa dari 20 siswa. Siswa yang belum memenuhi kriteria ketuntasan minimal adalah 15\% atau 3 orang siswa dari 20 siswa. Nilai terendah siswa pada post-test siklus II adalah 60, sedangkan nilai tertinggi adalah 100. Hasil tersebut menunjukkan bahwa hasil belajar siswa pada siklus II sudah mencapai target keberhasilan yaitu 85\%. Oleh karena itu penelitian dicukupkan sampai siklus II. 
Data persentase ketuntasan pada siklus II yang telah diperoleh siswa kemudian dibandingkan dengan persentase tingkat ketuntasan Siklus I. Hal ini dilakukan untuk mengetahui seberapa besar peningkatan yang terjadi setelah ada perbaikan tindakan pada siklus II. Berikut ini adalah perbandingan nilai siswa.

Tabel 5. Perbandingan Hasil Belajar Siswa Pre-test, Post-test Siklus I dan Siklus II

\begin{tabular}{|c|c|c|c|c|c|}
\hline No & Nama Siswa (Inisial) & Nilai Pre-test & $\begin{array}{l}\text { Nilai } \\
\text { Siklus I }\end{array}$ & Post-test & $\begin{array}{l}\text { Nilai Post-test } \\
\text { Siklus II }\end{array}$ \\
\hline 1 & ADNS & 60 & 80 & & 80 \\
\hline 2 & ATP & 50 & 40 & & 60 \\
\hline 3 & $\mathrm{DA}$ & 80 & 90 & & 80 \\
\hline 4 & DPR & 70 & 70 & & 90 \\
\hline 5 & FAN & 50 & 60 & & 80 \\
\hline 6 & FR & 60 & 100 & & 90 \\
\hline 7 & $\mathrm{FF}$ & 80 & 80 & & 80 \\
\hline 8 & $\mathrm{HN}$ & 90 & 100 & & 100 \\
\hline 9 & MKA & 40 & 60 & & 70 \\
\hline 10 & MTK & 60 & 90 & & 90 \\
\hline 11 & NPV & 90 & 80 & & 90 \\
\hline 12 & NR & 60 & 100 & & 100 \\
\hline 13 & RER & 60 & 90 & & 100 \\
\hline 14 & RCD & 70 & 80 & & 100 \\
\hline 15 & RA & 60 & 100 & & 90 \\
\hline 16 & RPM & 30 & 60 & & 60 \\
\hline 17 & SA & 80 & 80 & & 80 \\
\hline 18 & $\mathrm{TR}$ & 60 & 60 & & 90 \\
\hline 19 & $\mathrm{FF}$ & 80 & 80 & & 90 \\
\hline 20 & FIH & 60 & 60 & & 70 \\
\hline \multicolumn{2}{|c|}{ Jumlah } & 1290 & 1560 & & 1690 \\
\hline \multicolumn{2}{|c|}{ Rata-rata } & 64,5 & 78 & & 84.5 \\
\hline \multicolumn{2}{|c|}{ Nilai Tertinggi } & 100 & 100 & & 100 \\
\hline \multicolumn{2}{|c|}{ Nilai Terendah } & 30 & 40 & & 60 \\
\hline \multicolumn{2}{|c|}{ Ketuntasan (\%) } & $30 \% \%$ & $65 \%$ & & $85 \%$ \\
\hline & persentase ketuntasan & - & $20 \%$ & & \\
\hline
\end{tabular}

Apabila dilihat dari nilai yang diperoleh siswa pada siklus I dan siklus II, materi keliling bangun datar hampir semua siswa telah mengalami peningkatan. Peningkatan nilai hasil tes keliling bangun datar siswa pada pre-test (pra-tindakan), post-test siklus I, dan post-test siklus II juga dapat dilihat dalam diagram batang berikut ini. 


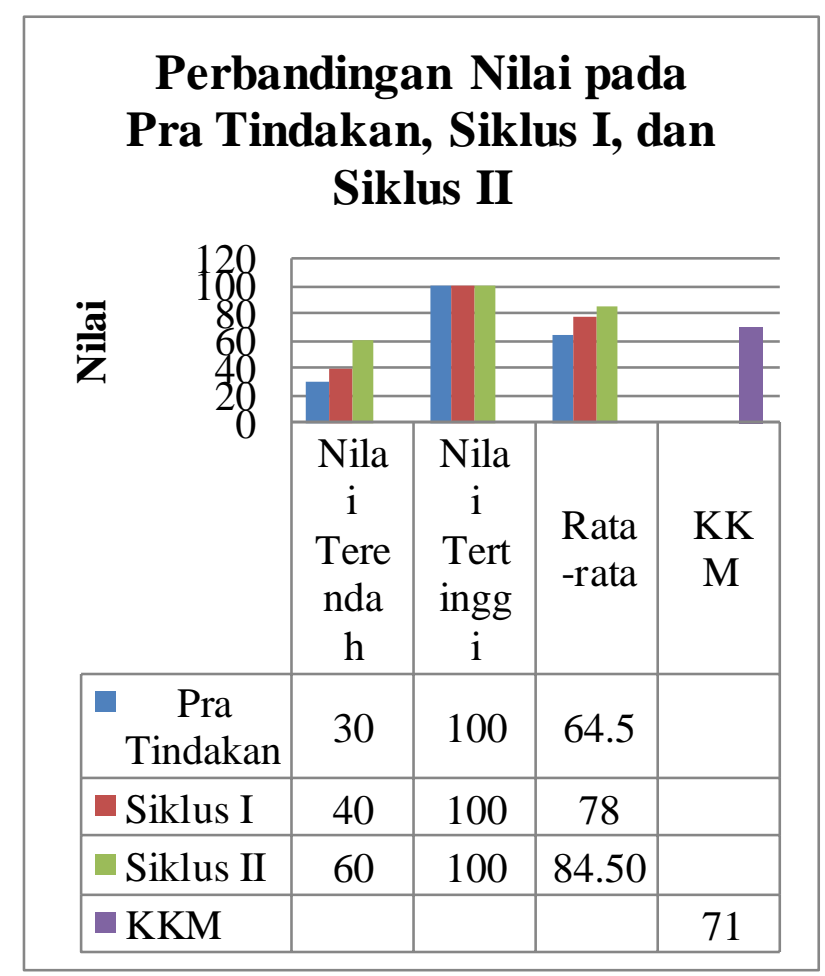

Gambar 5. perbandingan nilai pra-tindakan

Berdasarkan hasil tabel dan gambar perbandingan nilai pra-tindakan, siklus I, dan siklus II menunjukan bahwa adanya kenaikan di setiap siklusnya. Nilai terendah pada pra-tindakan adalah 30 , meningkat menjadi 40 di siklus I, dan 60 Siklus II. Nilai tertinggi yang diperoleh pada pra-tindakan, siklus I, dan siklus II adalah 100. Rata-rata terakhir pada siklus II mencapai 84,5.

\section{Simpulan}

Berdasarkan hasil penelitian tindakan kelas yang dilaksanakan dalam dua siklus dan di paparkan pada bab sebelumnya, peneliti dapat menyimpulkan bahwa hasil belajar siswa kelas III SD Negeri 1 Granting mengalami peningkatan setelah diterapkan model pembelajaran Problem Based Learning dan Make a Match di dalam pembelajaran matematika di kelas tersebut.

Peningkatan baik proses maupun hasil belajar siswa dapat dilihat dari hasil observasi dan hasil post-test siklus I dan siklus II yang dapat peneliti simpulkan, yaitu meningkatnya persentase ketuntasan siswa. Pada kondisi awal sebelum dilaksanakan tindakan persentase ketuntasan siswa adalah 30\%, dan pada siklus I persentase ketuntasan siswa meningkat menjadi 65\%, sedangkan pada siklus II persentase ketuntasan siswa juga meningkat menjadi $85 \%$. Dari hasil tersebut, sudah $\geq 80 \%$ siswa yang mencapai Kriteria Ketuntasan Minimal (KKM) pada siklus II, dan dapat diketahui bahwa penerapan model pembelajaran Problem Based Learning dan Make a Match dapat dilaksanakan untuk meningkatkan kualitas pembelajaran Matematika di kelas III SD Negeri 1 Granting sehingga dapat meningkatkan hasil belajar siswa.

Berdasarkan kesimpulan yang telah dipaparkan di atas, maka sebagai upaya meningkatkan proses pembelajaran terdapat beberapa saran sebagai berikut:

1. Bagi guru Bagi Guru

a. Sebaiknya guru dalam mengajar menggunakan model pembelajaran Problem Based Learning dan Make a Match sehingga siswa menjadi lebih tertarik dan pembelajaran akan menjadi lebih menyenangkan dan bermakna. Hal tersebut membuat siswa tidak mudah bosan dan tetap termotivasi untuk mengikuti proses pembelajaran yang pada akhirnya dapat meningkatkan hasil belajar disetiap mata pelajaran.

b. Dalam menyampaikan materi sebaiknya guru menunjukkan atau lebih menekankan pada langkah-langkah Problem Based Learning dan Make a Match karena dapat memberikan kemudahan bagi siswa untuk memahami, dan juga akan menarik perhatian siswa sehingga pembelajaran menjadi lebih menarik.

c. Guru sebaiknya mengupayakan tindak lanjut terhadap pembelajaran dengan menggunakan model Problem Based Learning dan Make a Match pada pembelajaran yang akan dilaksanakan.

2. Bagi Siswa 
Siswa diharapkan untuk lebih giat dalam mempelajari Matematika baik keliling bangun datar maupun materi yang lainnya.

\section{Daftar Pustaka}

Arsyad, A. (2016) 'Jurnal Dimensi Pendidikan dan Pembelajaran Vol.5 Januari 2016 | 29', Jurnal Dimensi Penididikan dan pembelajaran, 5, pp. 29-37.

Assegaff, A. and Sontani, U. T. (2016) 'Upaya Meningkatkan Kemampuan Berfikir Analitis Melalui Model Problem Based Learning (Pbl)', Jurnal Pendidikan Manajemen Perkantoran, 1(1), p. 38. doi: 10.17509/jpm.v1i1.3263.

Hasratuddin (2013) 'Membangun Karakter Melalui Pembelajaran Matematika', Jurnal Pendidikan Matematika PARADIKMA, 6(2), p. 130-141. Available at: http://digilib.unimed.ac.id/id/eprint/960.

Kamarullah, K. (2017) 'Pendidikan Matematika Di Sekolah Kita', Al Khawarizmi: Jurnal Pendidikan dan Pembelajaran Matematika, 1(1), p. 21. doi: 10.22373/jppm.v1i1.1729.

Lestari, D. D., Ansori, I. and Karyadi, B. (2017) 'Penerapan Model Pbm Untuk Meningkatkan Kinerja Dan Kemampuan Berpikir Kritis Siswa Sma', Diklabio: Jurnal Pendidikan dan Pembelajaran Biologi, 1(1), pp. 45-53. doi: 10.33369/diklabio.1.1.45-53.

Maesaroh, S. (1970) 'Peranan Metode Pembelajaran Terhadap Minat Dan Prestasi Belajar Pendidikan Agama Islam', Jurnal Kependidikan, 1(1), pp. 150-168. doi: 10.24090/jk.v1i1.536.

Novitasari, D. (2016) 'Pengaruh Penggunaan Multimedia Interaktif Terhadap Kemampuan Pemahaman Konsep Matematis Siswa', FIBONACCI: Jurnal Pendidikan Matematika dan Matematika, 2(2), p. 8. doi: $10.24853 /$ fbc.2.2.8-18.

Nurkholis (2013) 'PENDIDIKAN DALAM UPAYA MEMAJUKAN TEKNOLOGI Oleh: Nurkholis Doktor Ilmu Pendidikan, Alumnus Universitas Negeri Jakarta Dosen Luar Biasa Jurusan Tarbiyah STAIN Purwokerto', 1(1), pp. 24-44.

Sulastri and Dkk (2014) 'Meningkatkan hasil belajar siswa melalui strategi pembelajaran berbasis masalah pada mata pelajaran IPS di', Jurnal Kreatif Online, 3(1). Available at: https://media.neliti.com/media/publications/113571-ID-meningkatkan-hasil-belajar-siswamelalui.pdf.

Syamsiara Nur, S. P. (2017) 'Efektivitas Model Problem Based Learning (Pbl) terhadap Hasil Belajar Mahasiswa Prodi Pendidikan Biologi Universitas Sulawesi Barat', 2(2), pp. 133-141. doi: 10.31219/osf.io/378f2. 